\title{
GENDER AND NATURAL DISASTERS
}

"Specifically engaging those groups most vulnerable to disasters is an essential part of building disaster-resilient communities" (9)

\section{Why are women more vulnerable?}

Women are made more vulnerable to disasters through their socially constructed roles. As Elaine Enarson states "..gender shapes the social worlds within which natural events occur." (4)

- Women have less access to resources - social networks and influence, transportation, information, skills (including literacy), control over land and other economic resources, personal mobility, secure housing and employment, freedom from violence and control over decision-making - that are essential in disaster preparedness, mitigation and rehabilitation.

- Women are victims of the gendered division of labour. They are over-represented in the agriculture industry, self-employment and the informal economy, in under-paid jobs with little security and no benefits such as healthcare or union representation. The informal and agricultural sectors are usually the most impacted by natural disasters, thus women become over-represented among the unemployed following a disaster.

- $\quad$ Because women are primarily responsible for domestic duties such as childcare and care for the elderly or disabled, they do not have the liberty of migrating to look for work following a disaster. Men often do migrate, leaving behind very high numbers of female-headed households. The failure to recognize this reality and women's double burden of productive and reproductive labour, means that women's visibility in society remains low, and attention to their needs is woefully inadequate.

- Because housing is often destroyed in the disaster, many families are forced to relocate to shelters. Inadequate facilities for simple daily tasks such as cooking means that women's domestic burden increases at the same time as her economic burden, leaving her less freedom and mobility to look for alternative sources of income.

- When women's economic resources are taken away, their bargaining position in the household is adversely affected.

- Disasters themselves can serve to increase women's vulnerability. Aside from the increase in female-headed households and the fact that the majority of shelter residents are women, numerous studies have shown an increase in levels of domestic and sexual violence following disasters. $(8,9)$.

- As one of the primary aspects of women's health in particular, reproductive and sexual health are beginning to be recognized as key components of disaster relief efforts, however attention to them remains inadequate and women's health suffers disproportionately as a result.

\section{Women Responding to Disasters}

While we have seen that women are severely affected by natural disasters, this is only half the picture. Natural disasters often provide women with a unique opportunity to challenge and change their gendered status in society $(3,4,6)$.

- Women have proven themselves indispensable when it comes to responding to disasters. Following hurricane Mitch in 1998, women in Guatemala and Honduras were seen building houses, digging wells and ditches, hauling water and building shelters. Though often against men's wishes, women have been willing and able to take an active role in what are traditionally considered "male" tasks. This can have the effect of changing society's conceptions of women's capabilities.

- Women are most effective at mobilizing the community to respond to disasters. They form groups and networks of social actors who work to meet the most pressing needs of the community. This kind of community organizing has proven essential in disaster preparedness and mitigation (5).

- In response to increased levels of gender-based violence in Nicaragua following Hurricane Mitch, the NGO Puntos de Encuentro organized an information campaign that used various different media to transmit one simple message - "Violence against women is one disaster that men can prevent." The campaign proved very effective at changing men's attitudes towards violence against women (8).

- After the 1985 earthquake in Mexico City, women maquiladoras organized themselves into the 19 de septiembre Garment Workers' Union, which was recognized by the Mexican government and proved instrumental in lobbying for the recovery of women's employment. (4). 
- $\quad$ Following Hurricane Joan, women in Mulukutú, Nicaragua organized to develop plans for disaster preparedness that included all the members of a household. Consequently, Mulukutú was better prepared for Hurricane Mitch and it recovered more quickly than other similarly affected communities (3).

- As a result of their disaster response efforts, women are developing new skills such as natural resource and agricultural management which, in the right environment, they could carry over into the job market.

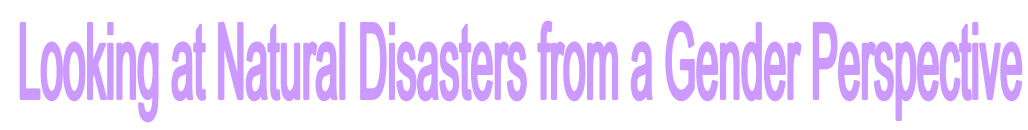

- Immediately following a disaster, the "tyranny of the urgent" prevails and gender concerns are overlooked or dismissed as irrelevant. The unique opportunity to change traditional gender roles that a disaster situation awards is wasted if women do not take advantage of it, or if decision-makers ignore it. Organization by women at the community and national levels is essential if recovery measures are to respond to women's needs and concerns $(3,4)$.

- A narrow view of the consequences of disaster leads to a focus on the purely physical, the social realities are ignored and, again, gender concerns are marginalized. Women will continue to be disproportionately affected by natural disasters unless disaster workers and officials acknowledge their vulnerable status and tailor relief efforts to respond to it.

- The majority of relief efforts are intended for the entire population of a disaster-affected area, however when they rely on existing structures of resource distribution that reflect the patriarchal structure of society, women are marginalized in their access to relief resources.

- A lack of harmony between disaster response measures and long-term development plans means that disaster preparedness is sacrificed in the face of disaster response efforts. Women's groups across the Americas have realized that the best way to mitigate the negative impact of a disaster is to be prepared for it. Women have been strong advocates for preparedness measures at the community level because they understand what disaster means to the day-to-day realities of life.

- Advocates have stressed that what is necessary to bring a gender perspective to the study of natural disasters is research and analysis of data disaggregated by sex, pilot projects during the reconstruction phase, an open dialogue within communities and between communities and the national government and capacity-building for women before, during and after disasters have occurred.

- Finally, an absence of institutional capacity in gender analysis is reflected in relief efforts, which do not include a gender perspective in their norms and procedures. Again this means that women's particular needs, concerns and their potential for contribution are overlooked during disaster preparedness, response and reconstruction. This also serves to highlight the necessity for an organized, gendered approach to the study of natural disasters and their consequences (3).

- An effective development process must include both the needs and the potential contributions of women as well as men. A community-based disaster preparedness and response plan that takes women's physical, psychological, social and economic vulnerabilities into account will help to reduce women's vulnerability to disaster overall. A plan that goes even further to recognize women's abilities and include them in disaster relief efforts will help to change gendered beliefs about women. A gender-based approach to the study and analysis of natural disasters is essential in accomplishing this goal.

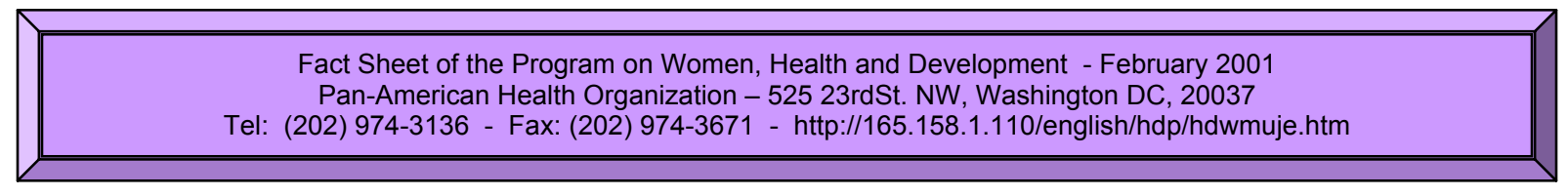

\section{REFERENCES}

1. Byrne, B. and S. Baden. "Gender, Emergencies and Humanitarian Assistance." Bridge Report 33 (Nov 1995) http://www.ids.ac.uk/bridge/reports/re33c.pdf

2. "Integrating Gender into Emergency Responses" Bridge Briefings 4 http://www.ids.ac.uk/bridge//dgb4.html

3. Shrader, E. and P Delaney. "Gender and Post-Disaster Reconstruction: The Case of Hurricane Mitch in Honduras and Nicaragua." World Bank Draft Report (January 2000). http://www.anglia.ac.uk/geography/gdn/resources/reviewdraft.doc

4. Enarson, E. "Gender and Natural Disasters" IPCRR Working Paper no.1. International Labour Organization (Sept 2000). http://www.ilo.org/public/english/employment/recon/crisis/publ/index.htm

5. "The Role of Women in Disasters" Disaster Preparedness in the Americas 34 (Apr 1998). Pan-American Health Organization. Available through the Virtual Disaster Library at http://www.vdl-bvd.desastres.net

6. Wiest, R. J. Mocellín and D. Thandiwe Motsisi. "El papel de la mujer en la etapa de reconstrucción y desarrollo" Desastres y Sociedad 4 (1995). http://osso.univalle.edu/co/tmp/lared/public/revistas/r4/art4.htm

7. Inventario de desastres en Centro América - Período 1960-1999. CEPREDENAC (1999). http://www.cepredenac.org/doc/inventar.htm

8. McCarrher, D.R and P.E. Bailey. "Evaluation of a Domestic Violence Mass-Media Campaign Targeted at Men - Campaña Desastre, Nicaragua." Family Health International (Jun 2000).

9. Enarson, E. "Surviving Domestic Violence and Disasters." Freda Centre for Research on Violence against Women and Children (Jan 1998) http://www.harbour.sfu.ca/freda/reports/dviol.htm 